\title{
Level of Micronutrient [Zinc] and its Association with Seizures in Children: A Case Control Study
}

\author{
Jehangir Allam*, Rajesh Kurmi, Roshan Ara, Santosh Kumar \\ Kurji holy family hospital Patna Bihar, India
}

*Corresponding author: Jehangir Allam Bhat, Kurji holy family hospital

Patna Bihar, India.

Received Date: September 04, 2018
Published Date: September 12, 2018

Published Date: September 12, 2018

\begin{abstract}
Objective: To determine the levels of serum zinc in children with febrile seizures when compared to children with fever without seizures and compare the levels of serum zinc in children with seizure due to CNS with febrile seizures and febrile children without seizures.

Methods: This was an observational case control study. Total 150 children of age Group6-60 months were included in study. 2 $\mathrm{ml}$ of blood from venipuncture within 24 hours of contact of patient in both the groups. Estimation of serum zinc was done within 6 hours of collection.

Results: Mean age of presentation in febrile seizures (GROUPA) was $22.14 \pm 15$ months, $24.26 \pm 17.2$ months in CNS infections (GROUPB) and 21.16 \pm 16.77 months control (GROUPC). Thus, most of the patients fall in age Group $<2$ years. Males predominated in present study with male female ratio of 2.9:1. Mean serum zinc level in febrile seizure (case) was $37.31 \pm 17.68 \mu \mathrm{gm} / \mathrm{dl}$ with lowest $14.3 \mu \mathrm{gm} / \mathrm{dl}$ and highest $98 \mu \mathrm{gm} / \mathrm{dl}$ and in CNS infections was $55.54 \pm 22.82 \mu \mathrm{gm} / \mathrm{dl}$ was observed. Thus, febrile seizures cases $\mathrm{n}=$ 45(90\%), CNS infections $n=33(66 \%)$ has biochemical hypozincemia i.e. serum zinc less than $65 \mu \mathrm{gm} / \mathrm{dl}$.
\end{abstract}

Conclusion: In febrile seizures and seizures due to CNS infection zinc deficiency could be a potential risk factor.

Keywords: Febrile seizure; Convulsion; Serum zinc level; Epilepsy

\section{Introduction}

Brain consists of nerve cells that usually communicate with each other through electrical activity thus, controls and regulates all voluntary and involuntary responses in the body. When region(s) of brain receives a burst of abnormal electrical signals that temporarily interrupts normal electrical brain function a seizure occurs. Transient occurrence of signs and or symptoms resulting from abnormal excessive or synchronous neuronal activity in the brain is defined as seizure. Febrile seizures are defined as the seizure that occurs between the age of 6 and 60 months with a temperature of $38{ }^{\circ} \mathrm{C}$ or higher that are not the result of CNS infections or any metabolic imbalance, and that occur in the absence of a history of prior afebrile seizures. Febrile seizure is either simple or complex. Febrile seizure that is primary generalized, usually tonic-clonic attack associated with fever, lasting for a maximum of $15 \mathrm{~min}$, and not recurrent within a $24 \mathrm{hrs}$ period is simple and febrile seizure that is more prolonged i.e.> $15 \mathrm{~min}$, is focal, and or reoccurs within $24 \mathrm{hrs}$ is complex [1]. Many children who have febrile seizures have genetic conditions [1]. Various factors have been described in the pathophysiology of febrile seizures like infections (Bacterial and viral) [2], temperature Susceptibility of immature brain [3], interleukins, circulating toxins association [4], micronutrient deficiency and iron deficiency [5].

Role of micronutrients like copper, zinc, magnesium and selenium [6] have been described in association with febrile seizures. Micronutrients appear to play a vital role by their ability to modulate neurotransmission by acting on ion channels as well as coenzyme activity. Zinc-containing glutaminergic neuron-rich areas i.e. the hippocampus and amygdala [limbic system] and the zinc homeostasis in this area of brain may be associated with the etiology and manifestation of epileptic seizures [7]. Zinc homeostasis in the brain is important for prevention of seizure development because it can act either as proconvulsant [8] or anticonvulsant [9]. Neuron terminals glutamate concentration(10Mm) in was estimated to be much higher than extracellular fluid $(<1 \mathrm{Mm})$ and vesicular zinc concentration(300Mm) [10]. The degree and balance of inhibition-excitation, which is associated with the etiology 
and manifestation of seizures is varied by excessive excitation of zinc -containing glutaminergic neurons when released into the synaptic clefts. Inhibitory effect of zinc on N-Methyl-D aspartate receptorsis responsible for excitatory phenomenon after binding with glutamate. Thus, decreased Zinc levels may play a role in pathogenesis of febrile seizures [11].

Since most of the research on zinc association with seizures is on febrile seizures, our focus of research was to show its association with febrile seizures and seizures due to CNS infections like meningitis and encephalitis.

\section{Material and Methods}

In this observational case-control study, total 150 children fulfilling the predefined inclusion criteria were studied during the period of 2 years, from May 2014 to May 2016 in Kurji Holy Family Hospital Patna Bihar. Ethical clearance was taken from hospital ethical team and proper consent was taken from parents/guardians of cases. Cases were divided into three equal groups.

\section{A. 1.GROUPA 50 febrile seizures (Cases) \\ B. 2.GROUPB 50 (CNS infections) \\ C. 3.GROUPC 50 Fever without seizures (Control)}

Children aged six months to five years with simple febrile seizures, complex febrile seizures, fever without seizures and seizure due to CNS infections (meningitis and encephalitis) were included in our study. Children having cerebral palsy, seizure disorder, chronic diseases, dysmorphic and syndromic features, children on zinc supplements and history of zinc supplementation in last 3 months, on anti-convulsant, acute and chronic diarrhea\& past history of neonatal seizures and metabolic disorders and any clinical feature thought to be due to zinc deficiency were excluded.

2-3 ml of blood from venous site using sterile needle, within 24 hours of contact of patient in both the groups after taking all aseptic precautions. The sample was centrifuged for 3-4 minutes at 3,0004,000 rpm, serum thus obtain and preserved in sterile deionized vial. Estimation of serum zinc was done within 6 hours of collection. Method used was based on colorimetric test kits, reagent used was 2-(5-bromo-2-pyridylazo)-5-(N-propyl-N-sulphopropylamino) phenol. Zinc forms a red chelate with it. Increase in the absorbance of wavelength $560 \mathrm{~nm}$ can be measured and is proportional to concentration of the zinc. As per WHO recommendation the cut off value for hypozincemia has been taken as $65 \mu \mathrm{gm} / \mathrm{dl}$ [12]. Hence $65 \mu \mathrm{gm} / \mathrm{dl}$ was taken as cutoff for hypozincemia.

\section{Statistical analysis}

Statistical Analysis of data was done using SPSS version 20.0 for windows. Zinc level presented as mean and standard deviation, the difference in mean among the groups was assessed by use of oneway ANOVA and t-test to analyze inter Groupdifference. A p-value less than 0.05 was taken as statistically significant.

\section{Results}

In our study as shown in Table 1. majority of the patients in all groups were of age Group $<2$ years and males predominated in present study with male female ratio of 2.9:1 (Table 2). Table 3 shows mean serum zinc level in GROUPA (febrile seizure) was $37.31 \pm 17.68 \mu \mathrm{gm} / \mathrm{dl}$ with lowest and highest levels of $14.3 \mu \mathrm{g} /$ $\mathrm{dl}$ and $98.2 \mu \mathrm{g} / \mathrm{dl}$ respectively. Mean serum zinc levels in GROUPB (CNS infections) was $55.54 \pm 21.82 \mu \mathrm{g} / \mathrm{dl}$ with lowest level of $17 \mu \mathrm{g} /$ $\mathrm{dl}$ and highest $122 \mu \mathrm{g} / \mathrm{dl}$. The mean serum zinc level in control was 67.19 \pm 20.6 ).

Table 1: Age distribution

\begin{tabular}{|c|c|c|c|}
\hline Age & Group a & Group b & Group c \\
\hline 12-Jun & $20(40 \%)$ & $20(40 \%)$ & $27(54 \%)$ \\
\hline $13-24$ & $20(40 \%)$ & $16(32 \%)$ & $7(14 \%)$ \\
\hline $25-36$ & $4(8 \%)$ & $4(8 \%)$ & $7(14 \%)$ \\
\hline $37-48$ & $1(2 \%)$ & $5(10 \%)$ & $6(12 \%)$ \\
\hline $49-60$ & $2(4 \%)$ & $5(10 \%)$ & $3(6 \%)$ \\
\hline TOTAL & $50(100 \%)$ & $50(100 \%)$ & $50(100 \%)$ \\
\hline
\end{tabular}

GROUP $A=$ febrile seizure group, GROUP $B=$ CNS infection group, GROUP C = Controls

Table 2: Gender distribution

\begin{tabular}{|c|c|c|c|}
\hline Sex & Group a & Group b & Group c \\
\hline Male & $40(80 \%)$ & $37(74 \%)$ & $35(70 \%)$ \\
\hline Female & $10(20 \%)$ & $13(26 \%)$ & $15(30 \%)$ \\
\hline Total & $50(100 \%)$ & $50(100 \%)$ & $50(100 \%)$ \\
\hline
\end{tabular}

GROUP A = febrile seizure group, GROUP B= CNS infection group, GROUP C $=$ Controls

Table 3: Serum zinc level comparison between febrile seizures and control group

\begin{tabular}{|c|c|c|c|c|c|c|c|c|c|}
\hline \multicolumn{10}{|c|}{ Serum Zinc Level in Micrograms/Dl } \\
\hline & \multicolumn{2}{|c|}{$<65$} & \multicolumn{2}{|c|}{$>65$} & \multicolumn{2}{|c|}{ Total } & \multirow{2}{*}{$\begin{array}{c}\text { Mean } \\
37.3 \pm 17.68 \\
\end{array}$} & \multirow{2}{*}{\begin{tabular}{|c|} 
Upper limit \\
98.2 \\
\end{tabular}} & \multirow{2}{*}{$\begin{array}{c}\text { Lower limi } \\
14.3 \\
\end{array}$} \\
\hline GROUP A & 45 & $90 \%$ & 5 & $10 \%$ & 50 & $100 \%$ & & & \\
\hline GROUP B & 33 & $66 \%$ & 17 & $34 \%$ & 50 & $100 \%$ & $55.54 \pm 21.82$ & 122 & 17 \\
\hline GROUP C & 20 & $40 \%$ & 30 & $60 \%$ & 50 & $100 \%$ & $67.14 \pm 20.69$ & & \\
\hline
\end{tabular}

GROUP A = febrile seizure group, GROUP B= CNS infection group, GROUP C= Controls

Statistically significant difference was observed between mean serum zinc in GROUPA (febrile seizure group) and GROUPC (Control group) with standard error of 3.98, mean difference of 29.88 and p value $<0.001$ and mean serum zinc level in GROUPB (CNS infection group) and GROUPC (control group) with the mean difference of 11.65 , $p$ value $=0.011$ and standard error of 3.98 (Table 4). 
Table 4: Statistical figures when groups where compared.

\begin{tabular}{|c|c|c|c|c|}
\hline Difference & Mean Value & Std. Error & $\begin{array}{c}\text { Signifi } \\
\text { cance }\end{array}$ & $\begin{array}{c}95 \% \\
\text { Confidence } \\
\text { Interval }\end{array}$ \\
\hline $\begin{array}{c}\text { GROUP A \& } \\
\text { GROUP C }\end{array}$ & $-29.8840000^{*}$ & 3.9856474 & 0.001 & -39.320791 \\
\hline $\begin{array}{c}\text { GROUP B \& } \\
\text { GROUP C }\end{array}$ & $-11.6580000^{*}$ & 3.9856474 & 0.011 & -21.094791 \\
\hline
\end{tabular}

\section{Discussion}

The present study was under taken in this context to study the correlation of serum zinc level with Febrile seizures, CNS infections presenting with seizures in comparison with febrile children without seizures.

In our study most of the patients had purely biochemical hypozincemia because as stated in methodology, patients having any clinical feature of zinc deficiency were excluded from the study. More than three fourth of the patients were below 24 months with mean age of $22.14 \pm 15$ months in febrile seizures (GROUPA), 24.26 \pm 17.2 months in CNS infections (GROUPB) and 21.16 \pm 16.77 months control (GROUPC). Mahyar et al. [13] reported similar observation, mean age $27.13 \pm 15.12$ months in cases and $28.49 \pm 16.5$ months control. Ganesh et al. [14] also reported mean age of 23.8 months in cases. Thus, this study shows febrile seizures are more common in age less than 24 months, as $40(80 \%)$ patients in febrile seizure Groupwas between 6-24 months.

Males predominated in present study with male female ratio of 2.9:1 in total 150 study population. In GROUPA (febrile seizures cases) 40 (80\%) patient was male, in GROUPB (CNS infections) 37 (74\%) were male and $35(70 \%)$ in control (GROUPC) were male gender. Other studies were having gender ratio 1.4-1 as reported by Park JR et al. [15]. Thus, this indicates the male predominance in febrile seizures.

In the present study, mean serum zinc level in febrile seizure was $37.31 \pm 17.68 \mu \mathrm{gm} / \mathrm{dl}$ and mean serum zinc level in control was $67.19 \pm 20.6$. Thus, significant difference of $29.88 \mu \mathrm{g} / \mathrm{dl}$ was observed in mean serum zinc level in cases as compared to controls with $p$ value $<0.001$ and standard error 3 .98. Similar findings have been reported by other researchers Ganesh R et al. [14], Okposio et al. [16], Mahyar et al. [13], Amiri et al. [6], Heydarian F et al. [17], Gattoo et al. [18].

In the present study mean serum zinc levels in GROUPB (CNS infections) of $55.54 \pm 21.82 \mu \mathrm{g} / \mathrm{dl}$ was compared with mean serum zinc level in control Group(67.19 $\pm 20.6 \mu \mathrm{g} / \mathrm{dl})$, the mean difference of 11.65 , p value $=0.011$ and standard error of 3.98 which is also statistical significant. Low serum zinc levels have been observed in cases of pyogenic meningitis may be secondary to disease process or it may be primary hypozincemia leading to septic meningitis. The reasons are multifactorial. One is an adaptive response intended to deprive invading pathogens of zinc. Secondly, zinc may be utilized by the organisms for growth and multiplication. Latit kumar et al. [19] also reported low serum zinc in CNS infections (pyogenic meningitis) of $70.9816 \pm 59.39 \mu \mathrm{g} / \mathrm{dl}$ and control Group120.0 $\pm 37.79 \mu \mathrm{g} / \mathrm{dl}$ with $\mathrm{p}<0.01$ (Table 1-4).

\section{Conclusion}

Serum Zinc level in febrile seizures and seizures due CNS infections patients is low as compared to WHO normal level. Hypozincemia is risk factor for seizures (both febrile seizures and seizures due CNS infections). Thus, it appears that presence of hypozincemia in presence of other risk factors may enhance the occurrence of febrile seizures explaining a possible correlation between low serum zinc levels and febrile seizures. However, large randomized control trials are recommended to analyze this association and if proven, the possibility of prophylactic zinc supplementation in reducing the risk of febrile seizures in such patients

\section{Acknowledgements}

The authors are highly thankful to the hospital administration, the paramedical staff of the paediatric department, hospital statistician, and computer operators for helping in conducting this research.

\section{References}

1. Robert M Kliegmann, Bonita F Stanton, Joseph W, St Geme III, Nina F Schor (2016) Nelson textbook of Pediatrics. (20 $0^{\text {th }}$ edn), Reed Elsevier India Private Limited, India, pp. 2823-2829.

2. Millichap JG, Millichap JJ (2006) Role of viral infections in the etiology of febrile seizures. Pediatr Neurol 35(3): 165-172.

3. Holtzman D, Obana K, Olson J (1981) Hyperthermia- induced seizures in the rat pup: a model for febrile convulsions in children. Science 213(4511): 1034-1036.

4. Virta M, Hurme M, Helminen M (2002) Increased plasma levels of pro-and anti-inflammatory cytokines in patients with febrile seizures. Epilepsia 43(8): 920-923.

5. Kumari PL, Nair MK, Nair SM, Kailas L, Geetha S (2012) Iron deficiency as a risk factor for simple febrile seizures--a case control study. Indian Pediatr 49(1): 17-19

6. Amiri M, Farzin L, Moassesi ME, Sajadi F (2010) Serum Trace Element Levels in Febrile Convulsion. Biol Trace Elem Res 135(1): 38-44.

7. Sterman MB, Shouse MN, Fairchild MD (1988) Zinc and seizure mechanisms. Morley JE, Sterman MB, Walsh JH (Eds), Nutritional modulation of neural function. Academic Press Diego, USA, pp. 307-319.

8. Pei Y, Zhao D, Huang J, Cao L (1983) Zinc-induced seizures: a new experimental model of epilepsy. Epilepsa 24(2): 169-176.

9. Williamson A, Spencer D (1995) Zinc reduces dentate granule cell hyperexcitability in epileptic humans. Nuroreport 6(11): 1562-1564.

10. Fukahori M, Itoh M, Oomagari K, Kawasaki H (1988) Zinc content in discrete hippocampal and amygdaloid areas of the epilepsy (El) mouse and normal mice. Brain Res 455 (2) 381-384.

11. Ebadi M, Wilt S, Ramaley R, Swanson S, Mebus C (1984) The role of zinc and zinc-binding proteins in regulation of glutamic acid decarboxylase in brain. Prog Clin Biol Res 144A: 255-275.

12. WHO (2004) World Health Organization and United Nations Children Fund. Clinical management of acute diarrhoea. WHO/UNICEF Joint Statement 8(3): 237-241.

13. Mahyar A, Pahlavan A, and Varaseth Nejah A (2008) Serum zinc level in children with febrile seizures. Acta Medica Iranica 46(6): 477-480.

14. Ganesh R, Janakiraman L (2008) Serum zinc levels in children with simple febrile seizure. Clin Pediatr (Phila) 47(2): 164-166.

15. Park JR (2007) Relationship between Recurrence in Febrile Seizures and Serum Zinc Levels. J Korean Child Neurol Soc 15(1): 20-25. 
16. Matthias OM, Sadoh W, Ofovwe G, Onyiriuka A (2012) Serum Zinc level in Nigerian children with febrile convulsion. Journal of Pediatric Neurology 10(3): 187-193.

17. Heydarian F, Vatankhah H (2012) The role of anemia in first simple febrile seizure in children aged 6 months to 5 years old. Neurosciences (Riyadh), 17(3): 226-229.
18. Gattoo I, Harish R, Hussain SQ. correlation of serum zinc level with febrile seizures. Int J Pediatr 16(3): 509-515.

19. Kumar L, Chaurasiya OS, Gupta AH (2011) Prospective Study of Level of Serum Zinc in Patients of Febrile Seizures, Idiopathic Epilepsy and CNS Infections. People's Journal of Scientific Research 4(2): 1-4. 